\title{
INTRODUCTION OF BUDGETING FOCUSED ON THE RESULT (COMPARATIVE LAW RESEARCH)
}

The last four years in the Russian Federation are marked by a radical change of a budgetary paradigm, the essence of which is the transition from cost management to results management. It means that any budgetary plan should have a system of budgetary policy targets as its logic continuation and embodiment. These purposes should influence final social and economic results - the condition of public relations and the level of material and non-material values in a society that are provided by budgetary financing. This criterion, not the formal execution of an expenses budget, should determine an estimation of budgetary activity and a degree of its efficiency. This concept is stated in details in the Decree of the Government of the Russian Federation No.249 of May 22, 2004 "About Measures on Increase of Productivity of Budgetary Charges"'.

It is necessary to note that no country of the world that tried similar change of budgetary ideology managed to pass it quickly and without difficulties, no country of the world could find unique answers to many questions concerning the change of the style of finance management which have been formed for centuries.

The experience of other states in this sphere is of great interest for Russia.

The first attempt to create and introduce the results-oriented budgeting system was undertaken in the USA at the end of 1940s - the beginning of 1950s. In 1949 the special commission on development of suggestions aimed at perfection of organization and activity of the executive branch (The Commission on the Organization of the Executive Branch, also known according to the name of its leader as "Hoover Commission") offered essentially new format of the budget named "performance budget" that was focused not on the expenses of state resources but on productivity of state functions performance. The new approach got its legal expression in "Budget and Accounting Procedures Act" (Budget and Accounting Procedures Act, 1950). 
In 1965 the United Nations Organization issued "A Manual for Program and Performance Budgeting". It popularized ideas of a new budgetary planning model as "consisting of interconnected elements of a program structure, a system of financial data reporting and financial management in combination with classification and measurement of efficiency". The document also contained the definition of the results-oriented budgeting as reflection of "tasks and purposes for which budgetary financing, cost of programs developed to achieve these purposes, and the quantity indicators describing realization of the given programs are necessary"2.

The experience of New Zealand ${ }^{3}$ is often considered as one of the most consecutive and successful variants of results-oriented budgeting. When in 1984 the labor government came to power, the system of contract registration of obligations on achievement of purposes provided by budgetary financing (Performance Agreements) became very popular in this country. This system covers the whole chain of participants of an administrative process: the ministries, agencies subordinated to them, organizations financed from the budget, heads and workers of state bodies and organizations financed from the budget. Legal registration of relations arising at all levels of activity results planning, mutual rights and duties of participants of these relations are pointed out by researchers among advantages of the New Zealand model.

The strategy of public finances reforms was determined by the Public Finance Act issued in 1989 (The Public Finance Act, 1989). It stated that in contrary to traditional system of budgetary management, where the data for incoming resources (salary of the personnel, transport, fuel and communication costs, capital investments are the basis for decision-making, the system of public finances management should be based on parameters of productivity which include such concepts as "product" and "results of activity". Thus the basic documents for the system of state bodies should be agreements on achievement of productivity (performance agreements). They should be concluded between the government and its departments that are responsible for granting these or those public benefits, and the subject of these agreements should be rendering services (delivery of a product) for the following fiscal year.

The outcomes of a New Zealand new model of the results-oriented budgetary process are significant:

2 A Rose. Results-Oriented Budget Practice in OECD Countries. - London. Overseas Development Institute, 2003, p. 7.

3 More information on the budgetary reform in New Zealand see: A. Kibblewhite, C. Ussher. Outcome-focused Management in New Zealand. OECD Journal on Budgeting, 2002, No.1 (4), pp. 7-34; A. Schick. The Spirit of Reform: Managing the New Zealand State Sector in a Time of Change. Wellington. State Services Commission, 1996; J. Pallot. Centrale State Government Reforms. Report on New Zealand. Berlin 1999. 
Public expenses rate decreased from 40 - 44\% of GDP at the beginning of 1990s to $35 \%$ of GDP; infrastructure costs rate - by $50-60 \%$. Within 17 years after the reforms have been completed, the government for the first time began to execute the budget with surplus. A share of state manufacture in GDP during the years of reforms decreased from $12 \%$ to $5 \%$, and the total number of people involved in the state administration system - from 86.000 to 36.000 people ${ }^{4}$.

Among the countries of continental Europe, legal traditions of which are close enough to Russia, Spain was one of the first countries that started introduction of results-oriented methods in the budgetary activity. The beginning of this process started when in 1977 a new Budgetary Law (Ley General Presupuestaria) appeared. It obliged the government to formulate the budget by using purposes and programs. The Constitution of Spain signed in 1978 fixed the main principles of modernization of the public finance management expressed in the following constitutional norms: granting public services should be economic and effective (Article 31.2) and productive (Article 103). Since 1982 the Ministry of Economy and Finance of Spain demanded from departments to formulate their budgets as programs. By the end of 1980s there were changes in the sphere of budgetary reform: the definition of a new budget format was deemphasized and the budgetary process was emphasized. The purpose of financial department of Spain was to transform budgetary and procedural rules into the mechanism which would promote the introduction of the budget of results.

Summing up the results of two decades from the time when results-oriented principles of budgeting were introduced in Spain, Eduardo Zapico-Goni marks, as one of the main lessons of this experience, necessity to pay special attention to issues of not only legal regulation of reformed relations but also to create the culture of law enforcement of regulations stated in new legislative acts. In particular, the author points out that: "Attempts of the Ministry of Finance are focused, first of all, on the development of new laws and instructions. It is necessary to take measures to estimate and strengthen the influence of reforms on developing relations. Now the reform is limited by legislation, as well as the amendments of regulations on budgetary process, budgetary account and control, which results from both lack of political support for the changes and the prevalence of the normativist approach to the reforms".

People in charge of budgetary funds present their financial proceedings and information system in conformity with requirements of the Ministry of Finance but they do not find them beneficial for their own administrative interest. The strategy of reforms is based on hierarchical inter-subordination, on the assumption of reforms aims as something that goes without saying and on the belief in power of norms and 
rules and natural professionalism. Normativist and hierarchical traditions go back to the old times. There is a belief that new norms can bring success simply due to the fact that they are correct and legislatively fixed".

The example of more "flexible" and decentralized model of results-oriented budgetary planning, based on the initiative of executive bodies rather than on imperative legislative instructions, is Finland. Finland started the process in 1988 with trial projects carried out in some agencies and in 1995 new principles of public finance management were distributed in the whole budgetary sector. Contracts - socalled agreements on activity results concluded between ministries and agencies (Performance Contracts) constitute an important form of fixing budgetary legal relations. On the other hand, in New Zealand for example, the arrangement order of the given agreements is not settled by the legislation, and all questions concerning their conclusion and performance are the discretion of executive bodies. According to Jon R. Blondal, Jens Kromann Kristensen and Michael Ruffner, "only few aspects of a reform are initiated by legal acts, and it emphasizes that the responsibility for realization of reforms belongs to the ministries and agencies. Actually, the issues concerning a form and contents of a reform are solved by branch ministries and agencies within wide parameters established by the Ministry of Finance".

The People's Republic of China represents the example of gradual introduction of results-oriented principles of budgetary activity based on the selection of trial regions and trial programs which were to test and approve a new method.

The Government of China chose the province Guangdong, located in the south of the country, as the first trial territory. The experiment on the introduction of the results-oriented budgetary planning started there in 2003. The experience of Canada, France, the UK and the USA was preliminary investigated in details and taken as the basis. A special division for estimation of activity productivity, responsible for analytical and methodological support of the reform, was created in the department of finances of the province.

Originally, six projects administered by different departments were chosen to develop a new model of budgeting:

1) Creation of technology park for private enterprises (Department of Science and Technologies);

2) Reorganization of the elementary school system in mountain and backward districts in sixteen cities (Department of Education);

5 E. Zapico-Goni . Budget for Results in Spain: Lessons Learned after Two Decades of Reform. OECD Journal on Budgeting 2003, vol. 4, No.2, p. 45.

6 J. Blondal, J. Kristensen and M. Ruffner. Budgeting in Finland. OECD Journal on Budgeting 2002, vol. 2, No. 2, p. 27. 
3) Construction of high-speed routes in sixteen poor districts (Department of Transport, Department of Roads);

4) Foundation of universities within the framework of the $10^{\text {th }}$ five-year plan (Department of Education);

5) Reorganization of commercial and industrial corporation assets (Commercial and Industrial Corporation);

6) Development of tourism as a means of support for poor districts (Department of Tourism).

Despite many problems which arose during the reform, its first results were considered successful ${ }^{7}$.

According to the comparative analysis, the outcomes of results-oriented methods of budgetary planning introduced in different states have some essential peculiarities. It is possible to single out a number of common tendencies and features peculiar to the given process and determine its essence at the same time.

1. Distribution of budget expenses is carried out not according to the types of expenses but according to the purposes of activity and programs of authorities. The budget and other results-oriented documents are considered as a united program and budgetary complex.

2. Development and performance of plans, programs and other similar documents that determine tasks and purposes of authorities for the certain prospect, both development and performance of the budget are mutually integrated and represent a united procedural mechanism.

3. Efficiency of budget expenses is defined by a degree of result achievement which is expressed in a quantitative or qualitative way.

4. People in charge of budgetary assets, within the limits of their competence, possess a lot of freedom in financial resources management and bear responsibility for results.

5. Reporting on the budget performance includes not only financial parameters but also the ones describing management quality and productivity of budgetary funds use.

6. Introduction of results-oriented budgetary planning represents a long, stepby-step process that requires constant political support from the higher authorities of a country and appropriate legislative security, a serious reform 
on organization and functioning of the whole system of public authority and budgetary sector of a country, training of a significant amount of the qualified personnel.

The main problems that almost all countries face during the implementation of the results-oriented budgetary planning model are:

1. A high degree of resistance of administrative culture focused on former methods of budgetary activity with a slant on the observance of formal requirements of legislation during the budgetary process; inability of a significant amount of participants of a budgetary process to think with such categories as "efficiency", "productivity" and to use new administrative technologies in their activity.

2. Labour intensiveness and high expenses for national of account and reporting system adaptation, including government statistics, to the needs of resultsoriented budgetary planning system.

3. Difficulties in formulation of quantitatively measured purposes of programs. It is objectively impossible to measure separate results of activity exactly, to connect them with another concrete program.

4. A problem of personification of tasks on results achievement that some public authority bodies are responsible for. 


\section{Streszczenie}

Ostatnie cztery lata w finansach publicznych Federacji Rosyjskiej przebiegały pod wpływem radykalnych zmian w budżecie, których istota dotyczyła przejścia od modelu zarządzania kosztami do modelu zarządzania rezultatami. Jak wskazuje analiza porównawcza, główne problemy, na które napotykają prawie wszystkie kraje wprowadzające w swoich finansach publicznych planowanie budżetowe oparte na rezultatach są następujące:

1) wysoki stopień wytrzymałości kultury administracyjnej skoncentrowanej na obowiązujących metodach gospodarki budżetowej z uwzględnieniem formalnych wymogów legislacyjnych w trakcie procedury budżetowej,

2) intensyfikacja i wzrost wydatków krajowych budżetów,

3) problemy w formułowaniu sposobów mierzenia celów programów,

4) problem w personifikacji zadań skierowanych na osiagnięcie rezultatów, za które odpowiedzialne są określone organy publiczne. 